\title{
Hypomethylation Profile
}

National Cancer Institute

\section{Source}

National Cancer Institute. Hypomethylation Profile. NCI Thesaurus. Code C129893.

The identification and quantitation of sites for DNA hypomethylation in the genome of a biological sample. 